\title{
JUSTIFYING ARGUMENTS ABOUT SELECTION PROCEDURES FOR JUDGES AT INTERNATIONAL COURTS AND TRIBUNALS: A RESPONSE TO NIENKE GROSSMAN
}

\author{
Cecily Rose*
}

\section{Introduction}

This contribution considers why states as well as international courts and tribunals should act to remedy the gender imbalance on international benches. In my view, the most appropriate question is not why they must, but why they should. Arguments that states are legally bound under the UN Charter to address this gender imbalance are weak, though human rights law does provide a basis for claims that states must take action. But arguments about legitimacy — both normative and sociological—could provide a more persuasive basis for arguing that states as well as courts and tribunals should act. In particular, the normative legitimacy of international courts and tribunals could benefit from selection procedures designed to help ensure that states nominate the most meritorious candidates for judgeships.

Nienke Grossman's article on "Achieving Sex-Representative International Court Benches" provides an excellent launching point for this discussion about the need for reform. ${ }^{1}$ In her view, the "why" can be answered by pointing to legal obligations in the UN Charter and a number of human rights treaties, as well as the importance of fostering the sociological legitimacy of international courts and tribunals. Grossman does not, however, focus on how the normative legitimacy of these institutions could be enhanced by selection processes that are designed to ensure the appointment of the most meritorious individuals, which would in all likelihood include more women. Grossman notes that merit is not currently the "driving factor in the international judge-selection process," as "international judgeships are often used to reward political loyalty or advance political agendas, rather than to select the most qualified or meritorious candidates."2 But Grossman's proposals appear to be motivated primarily by the need to address a persistent gender imbalance rather than by the prevalence of selection procedures that are not necessarily designed to ensure the selection of the most qualified candidates. In my view, nonmeritorious selection procedures are the main problem, and the gender imbalance that we see across international courts and tribunals is a manifestation of it.

This piece argues that the goal of achieving international benches comprised of highly qualified men and women alike ought to be one of the main justifications for why states and international courts and tribunals should reform selection processes. The normative legitimacy of these institutions depends in part on benches comprised of the most qualified individuals of both genders. The steps that Grossman proposes-greater transparency and institutionalized screening-would ideally help to address the gender imbalance while also

\footnotetext{
* Assistant Professor, Grotius Centre for International Legal Studies, Leiden Law School.

Originally published online 09 September 2016.

${ }^{1}$ Nienke Grossman, Achieving Sex-Representative International Court Benches, 110 AJIL 82 (2016).

$2 \underline{I d}$. at 86.
} 
enhancing the overall quality of the judiciary at international courts and tribunals. In explaining or justifying the need for such reforms, we ought to rely more on arguments about legitimacy, and abandon the contention that such efforts are legally grounded in Article 8 of the UN Charter.

\section{Moving Away From the UN Charter and Human Rights Law}

According to Article 8 of the Charter, "[t]he United Nations shall place no restrictions on the eligibility of men and women to participate in any capacity and under conditions of equality in its principal and subsidiary organs." 3 In their seminal article on feminist approaches to international law, Hilary Charlesworth, Christine Chinkin, and Shelley Wright noted that the drafters of the Charter included this provision, at the insistence of the Committee of Women's Organizations, to ensure that women would serve as permanent UN staff members. ${ }^{4}$ The drafters apparently phrased Article 8 as a negative rather than a positive obligation out of deference to member states that were concerned about their freedom to choose delegates and representatives to the United Nations. Charlesworth, Chinkin, and Shelley lamented the extent to which women's appointments within the United Nations had not attained the promise of Article 8 as of 1991, when the three published their article. ${ }^{5}$ They figured that at the rate of change they were observing at that time, the representation of men and women at the United Nations would not achieve parity until 2021.6 If we turn our gaze from the United Nations to international courts and tribunals as a whole, 2021 now seems like a wildly optimistic goal for parity on the bench.

In Grossman's estimation, Article 8 forms the basis for the assertion that "[s]tates are legally required to take steps to understand and remedy the paucity of women judges on most international court benches." 7 Grossman extends this argument not only to the International Court of Justice (ICJ), the principal judicial organ of the United Nations, but also to the International Criminal Tribunals for the former Yugoslavia and Rwanda, which are subsidiary organs of the UN Security Council, and the International Criminal Court (ICC), which has a special relationship with the United Nations. Grossman notes in particular that the Security Council can refer situations to the ICC, and the Negotiated Relationship Agreement between the ICC and the United Nations covers personnel matters.

For a number of reasons, Article 8 provides an inadequate legal basis for arguing that states must act to remedy the gender imbalance on international courts and tribunals. First, the subject of Article 8 is the United Nations itself, not its member states. Whereas other provisions of the Charter are directed to UN member states, or to member states and the United Nations itself, Article 8 is addressed to the organization alone. Because of this, it is difficult to argue that Article 8 creates a legal obligation for member states, as opposed to a legal obligation for the organization. Indirectly, Article 8 could result in legal obligations for member states if, for example, the United Nations were to implement this provision through internal administrative rules that require member states to refrain from placing restrictions on the eligibility of women to serve as representatives to the United Nations. But Article 8 itself binds the organization, not its member states, and therefore cannot be the basis for arguments about the legal obligations of states.

Second, the drafters of the UN Charter formulated Article 8 so as to impose a negative obligation on the United Nations not to take certain discriminatory action, rather than a positive obligation to create conditions

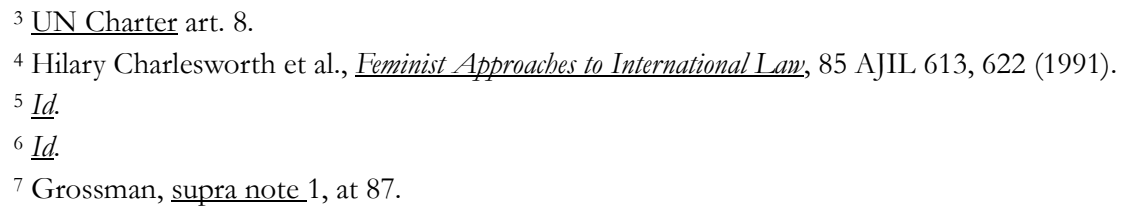


of equality. Many delegations apparently considered it to be unnecessary to include such a provision in the first place, as they regarded it as self-evident that the organization would not take overt steps against gender equality. In stating the obvious, however, the drafters ultimately took a notably conservative approach to gender equality, which merely prohibits overtly discriminatory gender policies at the United Nations. Though there are many reasons why the United Nations should encourage gender equality both within and outside of the organization, Article 8 does not actually require this. Article 8 does not oblige the ICJ, for example, to reform its procedures for the selection of judges or require states to reform their nomination processes.

Finally, even if Article 8 did provide a sound basis for arguing that states have a legal obligation to remedy the gender imbalance on international courts and tribunals, this obligation would only extend, at most, to four of the twelve courts that Grossman considers in her article. Highly active judicial institutions, such as the World Trade Organization's Appellate Body, the European Court of Justice, and the European Court of Human Rights, fall outside of the UN system and beyond the ambit of Article 8, regardless of how we interpret it.

But Grossman also mentions the Convention on the Elimination of all Forms of Discrimination Against Women (CEDAW), which does provide a basis for arguing that states (rather than judicial institutions) must act to remedy the gender imbalance at all international courts and tribunals, both within and beyond the UN umbrella.

Article 8 of CEDAW provides that "States Parties shall take all appropriate measures to ensure to women, on equal terms with men and without any discrimination, the opportunity to represent their Governments at the international level and to participate in the work of international organizations." 8 Unlike Article 8 of the UN Charter, Article 8 of CEDAW is directed towards states, as opposed to an international organization like the United Nations. It also imposes a positive, as opposed to a negative, obligation on states to promote gender equality. Moreover, this provision is specifically concerned with representation at the international level, and is therefore especially relevant for our purposes. A stronger legal basis for requiring states to remedy the gender imbalance may therefore be found in CEDAW rather than the UN Charter.

Ultimately, however, it may be most productive for scholars and advocates to focus not on what individual states must do under CEDAW, but on what international courts and tribunals should be requiring states to do on account of policy concerns rather than international law. Human rights law does not provide the strongest basis for justifying arguments about reforming selection procedures because these reform efforts will ideally be led by international courts and tribunals, which are not subjects of treaties like CEDAW. If individual states were to bring themselves into compliance with Article 8 of CEDAW by reforming their national selection procedures with respect to some or all international courts and tribunals, then this would certainly represent progress. But this would be a highly decentralized, and therefore potentially inefficient way of bringing about change. Instead, we would ideally see international judicial institutions taking the lead by requiring nominating states to comply with a uniform set of policies designed to enhance transparency and provide for screening. The ICJ, for example, could conceivably amend its Rules of Court so as to require nominating states to comply with certain rules about transparency and institutional screening. While such reform efforts would be in keeping with states' obligations under CEDAW, they would not be legally based on this instrument. We might consider Article 8 of CEDAW an important background norm, but it does not ground efforts to spur courts and tribunals to take action.

${ }^{8}$ Convention on the Elimination of All Forms of Discrimination Against Women art. 8, Dec. 18, 1979, 1249 UNTS. 
Reconsidering Arguments About Legitimacy

The strongest justifications for efforts to achieve greater gender parity on international benches may be found in arguments about legitimacy. ${ }^{9}$ Arguments about the normative legitimacy of international courts and tribunals arguably have the most important role to play, though arguments about sociological legitimacy could also play a significant role if researchers were to produce empirical studies that support claims about perceptions of international judicial institutions. Arguments about both types of legitimacy could provide support for the notion that international judicial institutions ought to take action to address persistent gender imbalances on the bench. Such arguments are grounded not in law, but in ideas about how these institutions justify their authority. This approach to justifying the need for reform entails a clear shift from arguments about what states (or international organizations) must do in a legal sense, to arguments about what international judicial institutions ought to do to strengthen their legitimacy.

The term legitimacy takes on a normative dimension when we speak, for example, about whether international courts and tribunals have a well-founded claim to authority, or whether their claim to authority may be objectively justified. ${ }^{10}$ Normative criteria in the context of international courts and tribunals might, for example, include the consent of the disputing parties or the procedural fairness of the decision-making process. ${ }^{11}$ Empirical or sociological legitimacy is a related but distinct concept. The term legitimacy takes on a sociological, as opposed to a normative dimension, when we speak about popular attitudes towards international courts and tribunals among states and individuals. Legitimacy in this sense is based on subjective perceptions or attitudes. The two can be related—an international court's popular legitimacy can be an element of its normative justification.

This distinction between normative and sociological legitimacy is worth emphasizing in the context of representation on international courts and tribunals because it may allow us to better appreciate why a meritorious selection process is significant. Selection processes that are designed to help ensure that international courts and tribunals are comprised of the most qualified candidates arguably contribute, in part, to the normative legitimacy of these institutions. Such selection processes can involve states implementing transparent nomination procedures at the domestic level, and they can also involve international courts and tribunals screening the nominees-both are sound prescriptions put forward by Grossman. Judicial institutions that benefit from these types of selection procedures may have a stronger claim to authority because the caliber of the bench has direct bearing on the quality of the institution's decision-making processes. This is not a claim that international courts and tribunals with well-qualified candidates are more legitimate because they are making substantively better decisions. Instead, the claim is that such institutions will potentially benefit from sounder decision-making processes on account of the quality of the bench. The normative legitimacy of international courts and tribunals is arguably weakened when merit is not a driving factor in the selection of judges.

Opaque nomination processes at the domestic level thus threaten normative legitimacy not necessarily because they may result in a gender imbalance on the bench, but because they have the potential to diminish the quality of the decision-making process. On the basis of current studies, it is difficult to argue that a gender imbalance, in itself, negatively impacts the decision-making process of international courts and tribunals. As

\footnotetext{
${ }^{9}$ For further arguments about legitimacy, see Neus Torbisco-Casals, Why Fighting Structural Inequalities Requires Institutionalizing Difference: A Response to Nienke Grossman, 110 AJIL UnBound 92 (2016).

${ }^{10}$ Daniel Bodansky, The Legitimacy of International Governance: A Coming Challenge for International Environmental Law?, 93 AJIL 596, 601 (1999).

11 See Nienke Grossman, The Normative Legitimacy of International Courts, 86 TEMP. L. REV. 61 (2013); Nienke Grossman, Sex on the Bench: Do Women Judges Matter to the Legitimacy of International Courts?, 12 CHI. J. INT'L L. 647 (2012).
} 
Grossman acknowledges, we currently lack sufficient evidence that a gender imbalance would negatively impact decision-making by international benches because male and female judges reason differently. ${ }^{12}$ Instead, a gender imbalance may be regarded as a symptom of nonmeritorious selection processes, and thus may be a sign of illegitimacy from a normative perspective. A gender imbalance is, in other words, a very visible potential consequence of nonmeritorious selection processes.

Meritorious selection procedures could also be significant from the perspective of sociological legitimacy because of the impact that they may have on the gender balance of international benches. Grossman argues, in essence, that the public's perception of international judicial institutions is negatively affected by benches that do not represent the general population. ${ }^{13}$ This argument has a considerable intuitive appeal. When I show my students photographs of the judges who sit on the international courts and tribunals that we study, they commonly remark upon or ask about the gender imbalance. Their perception of these institutions is evidently affected by what they view as a disproportionate number of men serving as judges. But this is merely anecdotal. Arguments about the perceived legitimacy of international judicial institutions are only viable if empirical studies can be cited in support of the notion that a gender imbalance fosters a negative public perception.

Arguments about sociological legitimacy can and should be supported by empirical studies involving surveys and interviews, for example. Surveys of populations affected by court decisions or interviews of government lawyers who have appeared before international courts and tribunals are, for example, potential sources of information about how these institutions are perceived. But the challenges involved in conducting empirical research on perceptions of international courts and tribunals could, admittedly, be daunting for researchers. Measuring the general public's perception of these institutions raises considerable challenges given, for example, the general public's relatively limited awareness of the various international courts and tribunals. ${ }^{14}$ In light of the fact that major newspapers often refrain from referring to international courts and tribunals by name, and instead use terms like "The Hague Court," surveys of the general public regarding details such as their composition could be fruitless. Do we really expect the general public to have an awareness of the composition of international courts and tribunals, when simply differentiating between them is, in itself, a significant problem? Yet, empirical studies of some sort are much needed-without them, claims about the sociological legitimacy of unrepresentative benches are supported only by our intuitions and anecdotes. In the future, I would like to be able to tell my students that their perceptions are in keeping with the results of empirical studies, and that efforts to reform selection processes are underway.

\section{Conclusion}

Proposals for the reform of judicial selection procedures for international courts and tribunals require carefully formulated justifications, in addition to well-crafted plans for change. As this piece argues, scholarship and advocacy on the composition of international benches should focus less on legal arguments grounded in the UN Charter and human rights law, and more on policy arguments about the legitimacy of these institutions. In particular, the normative legitimacy of international courts and tribunals stands to benefit from judicial selection procedures that are designed to help ensure that states nominate the most qualified candidates, both men and women. The sociological legitimacy of international courts and tribunals

\footnotetext{
12 Grossman, supra note 1 , at 89.

${ }^{13} \underline{I d}$. at 88 .

${ }^{14}$ But see, e.g., Harry M. Rhea \& Ryan C. Meldrum, United States Public Support for the International Criminal Court: A Multivariate Analysis of Attitudes and Attributes, 37 U. PA. J. INT'L L. 739 (2015); Erik Voeten, Public Opinion and the Legitimacy of International Courts, 14 THEORETICAL INQUIRIES L. 411 (2013).
} 
could also benefit from more diverse and qualified benches, but empirical research to support such claims is still a thing of the future. 